\title{
A Study on Landslide Risk Management by Applying Fault Tree Logics
}

\author{
Danish Kazmi ${ }^{1}$, Sadaf Qasim ${ }^{1}$, I.S.H Harahap ${ }^{2}$, Syed Baharom², Arjumend Masood ${ }^{1}$ and Muhammad Imran ${ }^{2}$ \\ ${ }^{1}$ Department of Civil Engineering, NED University of Engineering \& Technology, Karachi, Pakistan - 75270 \\ ${ }^{2}$ Department of Civil \& Environmental Engineering, Universiti Teknologi Petronas, Perak, Malaysia - 32610
}

\begin{abstract}
Slope stability is one of the focal areas of curiosity to geotechnical designers and also appears logical for the application of probabilistic approaches since the analysis lead to a "probability of failure". Assessment of the existing slopes in relation with risks seems to be more meaningful when concerning with landslides. Probabilistic slope stability analysis (PSSA) is the best option in covering the landslides events. The intent here is to bid a probabilistic framework for quantified risk analysis with human uncertainties. In this regard, Fault Tree Analysis is utilized and for prediction of risk levels, consequences of the failures of the reference landslides have been taken. It is concluded that logics of fault trees is best fit, to clinch additional categories of uncertainty; like human, organizational, and knowledge related. In actual, the approach has been used in bringing together engineering and management performances and personnel, to produce reliability in slope engineering practices.
\end{abstract}

\section{Introduction}

Learning from failures has long been a vital part of geotechnical engineering. Although there are many types of geotechnical failures, dam failures are especially significant and lean to be explored vigilantly. The dam failures at South Fork, Saint Francis, Malpasset, Vaiont, and the slope failure at Aberfan exhibit the consequences of failure, to tackle geotechnical and geological issues satisfactorily [1]. However, the failures also refers that an inadequate safety culture, overconfidence, and confused management are often more imperative than purely technical issues [1]. The problem of landslides in Malaysia is also dominated by these issues. This is not new; the catastrophic failure of Kwun Lung Lau landslide in Hong Kong is the outcome of human uncertainty. In this connection, this document involves current state of art in risk analysis to overcome or minimize the effects of slope failures. As in last few decades, the need to identify and quantify human uncertainties has not been accepted or catered fully by the geotechnical industry [2], [3], [4] and [5].

\section{Objectives of the study}

The objective of this study is to substantiate a need of human reliability analysis in geotechnical industry by putting numerous devastating slope failures into consideration. Secondarily, to overcome or minimize the effects of slope failures consequences, this study has developed fault tree analysis of significant scenarios responsible for slope failures
Table 1. Classes for probability of occurrence [8].

\begin{tabular}{|c|c|c|}
\hline $\begin{array}{c}\text { Qualitative } \\
\text { Evaluation }\end{array}$ & $\begin{array}{c}\text { Quantitative } \\
\text { Evaluation }\end{array}$ & Value \\
\hline Certain & Every time & 1.0 \\
\hline Very High & One in a ten & $10^{-1}$ \\
\hline High & One in a hundred & $10^{-2}$ \\
\hline Moderate & One in a thousand & $10^{-3}$ \\
\hline Low & One in ten thousand & $10^{-4}$ \\
\hline Very Low & $\begin{array}{c}\text { One in hundred } \\
\text { thousand }\end{array}$ & $10^{-5}$ \\
\hline Extremely Low & One in a million & $10^{-6}$ \\
\hline Practically Zero & One in ten million & $10^{-7}$ \\
\hline
\end{tabular}

\section{Methodology of the study}

The goal here is to bid a probabilistic framework for quantified risk analysis in relation with human uncertainties. As mentioned before, that Fault Tree Analysis (FTA) approach is employed by this study to overcome the likelihood situation of a catastrophe. The first step in quantifying a fault tree is to allot initial probabilities to the basic events. This step is taken by assembling information from a focus group decipherable with particular situations. The attached Table 1 is used as a channel for collecting this qualitative information. The group includes evaluation from registered professional engineers (civil and geotechnical), Contractors: from Pusat Khidmat Kontraktor (PKK), construction industry 
development officials and slope engineering division officials of Jabatan Kerja Raya Malaysia. Their opinions further justified by Aggregated Individual Method [6] however at few places Consensus Group Method [6] is also followed for the purpose of validation.

After having one concluded parameter of risk, "probability of failure", another parameter has been established bytaking selected case studies of Malaysian region. In case of following Santamarina and associates [7] approach, having in hand quantities of causalities and economic losses of the reference landslides can give an idea about risk levels to access whether the risk is acceptable or marginally acceptable.

\section{Results and discussions}

The above mentioned fault tree analysis technique is used to determine the chances of failure of the specific design, construction and maintenance subtasks (Refer Table 2) by fault tree logics.

Table 2. Probability of Failures of Selected Tasks/Scenarios.

\begin{tabular}{|c|c|}
\hline Scenarios & Probability of Failure \\
\hline Development plans & 0.75 \\
\hline $\begin{array}{c}\text { Testing/selection of shear } \\
\text { strength parameters }\end{array}$ & 0.124 \\
\hline Drainage planning/design & 0.001 \\
\hline $\begin{array}{c}\text { Installation/construction of } \\
\text { drains }\end{array}$ & 0.001 \\
\hline Retaining wall construction & 0.069 \\
\hline Soil nail wall construction & 0.068 \\
\hline Ground anchor maintenance & 0.025 \\
\hline Other slope strengthening works & 0.194 \\
\hline
\end{tabular}

With reference to a fault tree for selecting/testing the shear strength parameters, one of the fact discovered through expert analysis is that improper experimental setup has also been observed in many cases. According to the study of Tan and Gue [9], selection of appropriate shear strength parameters is very crucial in design of cut slopes. It is significant that, materials like residual soils have discontinuities which the small scale tests may sometimes unable to detect. On the other hand, largesized particles, effect cannot be quantitatively assessed and usually under-estimate the shear strength parameters of the in-situ material mass. Hence special care has to be taken in the selection of representative soil strength for slope stability analysis [9].

In reference to developing plans, "perception lacking" and "trend to follow thumb rules/patent methods" is quite high; according to quantitative estimation, it is one in ten. In fact, many of the problems identified in developing plans revolve around poor accountability towards the projects, no right person in making decision of the project due to lack of knowledge and experiences, no close coordination among stakeholders and lack of communication among project participants [10]. According to Oakes [11], the benefits of a good project development plans must include earlier identification of risks and issues; adoption of good practice; availability of skills and experience; improved communication; improved ability to allocate resources; improved predictability of project delivery; and greater confidence to take risks.

Regarding the flaws in construction of structures such as soil nail walls / retaining walls, no clear guidelines regarding installation and fixing of the bearing plates (in soil nail walls) exist. According to Chin and Meng [12], the designer should clearly indicate the constraints/steps in the relevant documentation, and the constructor should strictly obey the instructions of designer. It is recommended that stages of work for soil nailing to be included in construction drawings and relevant work specifications [12].

Among other slopes strengthening structures, "prestress ground anchors maintenance" involves unexpected diversion of water, blockage, seismic forces, soil mass movements improper coating on the anchors, sustained loading, environmental effects, seepage of water and material deficiency. Between the above mentioned basic events, subjective probability of seepage is reported quite high. It is approximately one in ten according to the given scale in Table 1. For the sake of maintenance, Malaysian local body Jabatan Kerja Raya (JKR) has also set some criteria and standards for monitoring and inspection for complex structures of ground anchors, surface subsurface drains, soil nailing etc. [13]. In slope strengthening structures, basic events of improper fixing and layout along with unknown cause plays a significant role which give rise to further event of obstruction in drainage. Water damming effect is also one of the events responsible to produce the abovementioned event among three primary events. The remaining two includes biased results through inclinometers and making an assumption that structures are maintenance free. This third primary event is totally illogical but as mentioned by Gue and Fong [14], this illogical approach also exists.

As already mentioned in the previous studies [15], [5], and [16], that consequence analysis requires some previous landslides for a reference. Consequences can be in terms of causalities (non-payable), property (payable) or environmental (long lasting). The risk level parameters can be established by taking reference of those landslides which have been occurred due to human errors and taking the empirical rates of failure, for civil engineering facilities estimated previously has been taken into account [17]. The reported landslides (Table 3 ), as investigated by the geologists and experts are the cases of design flaws, improper sequencing of construction and overall poor or non-maintenance factors. Specifically talking about Highland Tower collapse, inadequate and poorly maintained drainage is the major contributor. Design flaws are also prevailing but the collapse of the Highland Tower has been taken place after 15 years of construction. In case of the next two case histories selected in this study, Bukit Antarabangsa (1999) and (2008), one common feature among all three is the poor or inadequate drainage. Clogged drains or 
even no sign of berms drain construction noted in Bukit Antarabangsa 1999.

Table 3. Prominent human error cases of landslides

\begin{tabular}{|c|c|c|c|c|}
\hline Year & Location & Causes & Lives & RM(Million) \\
\hline \multirow{2}{*}{1993} & & Improper rubble walls [18] & 48 & 184.9 \\
\hline 1996 & Mighland Tower & Maintenance [19],[20],[21] & 44 & 69.0 \\
\hline 1996 & Kos Dipang & Design error [22],[20] & 302 & 458.9 \\
\hline 1999 & Kg. Gelam & Design error [20] & 17 & 29.5 \\
\hline 1999 & Bukit Antarabangsa & Design error [20] & - & 5.5 \\
\hline 2002 & Simunjan Sarawak & Design /construction & 16 & 28 \\
\hline 2002 & Taman Hillview & High infiltration [20] & 8 & 17.4 \\
\hline 2003 & Bukit Lanjan & Inadequate design of adjacent slope & - & 836 \\
\hline 2004 & Taman Harmonis & Adverse estimation of geological conditions [22],[20] & - \\
\hline 2006 & Taman Zooview & Design error [20] & 1 & - \\
\hline 2008 & Bukit Antarabangsa & Poor drainage [24],[20] & 4 & 20.7 \\
\hline
\end{tabular}

Table 4. Parameters for risk levels of major selected landslides.

\begin{tabular}{|l|l|l|l|l|}
\hline Location & Year & Pf & F & EC(RM) \\
\hline Highland Towers & 1993 & 0.194 & 48 & 184.9 \\
\hline Pos Dipang & 1996 & 0.001 & 44 & 69.0 \\
\hline Keningau & 1996 & 0.001 & 302 & 458.9 \\
\hline Kg. Gelam, Sandakan & 1999 & 0.001 & 17 & 29.5 \\
\hline Bukit Antarabangsa & 1999 & 0.75 & - & 5.5 \\
\hline Simunjan Sarawak & 2002 & 0.75 & 16 & 28 \\
\hline Taman Hillview & 2002 & 0.001 & 8 & 17.4 \\
\hline Bukit Lanjan & 2003 & 0.75 & - & 836 \\
\hline Harmonis, Gombak & 2004 & 0.001 & 1 & - \\
\hline Bukit Antarabangsa & 2008 & 0.194 & 4 & 20.7 \\
\hline
\end{tabular}

According to literature review, consequences of failure cannot be benchmarked [16]. As indicated for Bukit Antarabangsa 1999, the probability of failure is 0.75 (Table 4) but its original consequences reflect very minimal losses as compared to other landslides of Highland Towers and Bukit Antarabangsa 2008 (Table 4). The landslides of Bukit Lanjan Selangor and Simunjan Sarawak also carry a probability of failure of 0.75 but the losses occurred from all the three landslides are totally different with each other. This is now certain that, for risk evaluation of slope failures, probability of failure is a better option.

\section{Conclusion}

The development of fault trees is to clinch additional categories of uncertainty like human, organizational, and knowledge related. The results of fault tree logics are used to combine, engineering and management performances to furnish quality and reliability in slope engineering practices. The intent here is to propose a probabilistic framework for quantified risk analysis with human uncertainties. Formally, QRA emphasizes on measurement of probabilities and losses of the past scenarios which have been focused to predict the risk's severity.

\section{References}

1. Christian, J. T., "Failures and Reliability of Large Projects" Metropolitan Section, Geo -Institute Chapter ASCE, (2013).

2. Baecher, G. B. and Christian, J. T., Reliability and Statistics in Geotechnical Engineering: John Wile y \& Sons Inc, (200)3.

3. Morgenstern, N. R., "Managing risk in geotechnical engineering," in 10th Pan American Conference on Soil Mechanics and Foundation Engineering, (1995).

4. Stewart, R. A., "Dam Risk Management," in International Conference on Geotechnical and Geological Engineering (GeoEng2000), Melbourne, Australia, pp. 721-748, (2000).

5. Ho, K., et al., "Quantitative risk assessment: application, myths and future direction," 2000, pp. 19 $-24$.

6. Kirwan, B., "A Guide to Practical Human Reliability Assessment." Taylor \& Francis London, (1994).

7. Santamarina, J., et al., "Reliability of Slopes: incorporating Qualitative Information," Transportation Research Record (1992).

8. Kirsten, H., "Workshop on Evaluation of Risk as Decision Making with the Criterion," Denver, CO, (1999). 
9. Chin, T. Y. and Sew, G. S., "The Determination of Shear Strength in Residual Soils for Slope Stability Analysis," presented at the Seminar Cerun Kebangsaan, Cameron Highlands (2001).

10. Too, E., et al., "Project Governance in Malaysia Hillside Developments," in Sixth International Conference on Construction in the 21 st Century (CITC-VI) "Construction Challenges in the New Decade", Kuala Lumpur, Malaysia, (2011).

11. Oakes, G., "Project Reviews, Assurance and Governance" Aldershot, England; Burlington, VT: Gower, 2008.

12. Chin, T. Y. and Meng, C. C., "Slope Stabilization using Soil Nails Design Assumptions and Construction Realities," presented at the MalaysiaJapan Symposium on Geohazards and Geoenvironmental Engineering, Bangi, Malaysia, (2004).

13. Salahuddin, J. S., "Guidelines on Slope Maintenance in Malaysia," Slope Engineering Branch, Public Works Department Malaysia, (2006).

14. Gue, S. S. and Fong, C. C., "Slope safety: Factors and common misconceptions," Buletin Ingenieur, vol. 19, (2003).

15. Uzielli, M., et al., "A conceptual framework for quantitative estimation of physical vulnerability to landslides," Engineering Geology, vol. 102, pp. 251256, (2008).

16. Ellignwood, B., "Assessment and Mitigation of Risk from Competing Low- Probability High
Consequences Hazards," Symposium on Emerging developments in Multi-Hazard Engineering, (2007).

17. Baecher, G. B., "Geotechnical Risk Analysis Users Guide," FHWA/RD -87-011 Federal Highway Administration McLean, (1987).

18. Aun, O. T., "Mitigation And Rehabilitation of Natural Disasters In Malaysia," The Ingenieur, vol. 39, (2008).

19. Gue, S. S. and Tan, Y. C., "Landslides: Abuses of The Prescriptive Method," International Conference on Slope 2006 Kuala Lumpur, (2007).

20. Raya, J. K., "National Slope Master Plan" Sectoral Report Research and Development, vol. Jabatan Kerja Raya Malaysia, (2009).

21. Samah, F. A., "Landslide in hillside development in the Hulu Kelang, Klang Valley," presented at the Post -Graduate Seminar Universiti Teknologi Malaysia, (2007).

22. Jaapar, A. R. B., "A framework of a national slope safety system for Malaysia," University of Hong Kong, (2006).

23. Gue, S. S. and Liong, C. H. (2007). Is the Ground in Ulu Klang Unstable? www.gnpgroup.com

24. Aiun, O. T. and Miin, O. H., "Geotechnical Failures/Issues, Dispute Resolution and Mitigation," The Journal of the Institute of Engineers Malaysia, vol. 71, (2010)

25. JKR, "Jabatan Kerja Raya Final Investigation Report Investigation of Slope Failure at Taman Bukit Mewah, Bukit Antarabangsa Hulu Klang Salengor," (2009). 